\title{
An Expanded Three-Part Architecture for Post-2012 International Climate Policy
}

\section{Citation}

Olmstead, Sheila M., and Stavins, Robert N. 2009. An Expanded Three-Part Architecture for Post-2012 International Climate Policy. HKS Faculty Research Working Paper Series RWP09-036, John F. Kennedy School of Government, Harvard University.

\section{Published Version}

http://web.hks.harvard.edu/publications/workingpapers/citation.aspx?Publd=6911

\section{Permanent link}

http://nrs.harvard.edu/urn-3:HUL.InstRepos:4449104

\section{Terms of Use}

This article was downloaded from Harvard University's DASH repository, and is made available under the terms and conditions applicable to Other Posted Material, as set forth at http:// nrs.harvard.edu/urn-3:HUL.InstRepos:dash.current.terms-of-use\#LAA

\section{Share Your Story}

The Harvard community has made this article openly available.

Please share how this access benefits you. Submit a story.

\section{Accessibility}




\title{
Faculty Research Working Papers Series
}

\author{
An Expanded Three-Part Architecture \\ for Post-2012 International Climate Policy
}

Sheila M. Olmstead

Yale University

Robert N. Stavins

John F. Kennedy School of Government - Harvard University

December 2009

RWP09-036

The views expressed in the HKS Faculty Research Working Paper Series are those of the author(s) and do not necessarily reflect those of the John F. Kennedy School of Government or of Harvard University. Faculty Research Working Papers have not undergone formal review and approval. Such papers are included in this series to elicit feedback and to encourage debate on important public policy challenges. Copyright belongs to the author(s).

Papers may be downloaded for personal use only. 


\section{The Harvard Project on International Climate Agreements}

September 2009

Discussion Paper 09-29

\section{An Expanded}

Three-Part Architecture

for Post-2012

International Climate

Policy

Sheila M. Olmstead

School of Forestry and Environmental Studies

Yale University

USA

Robert N. Stavins

Harvard Kennedy School

Harvard University

USA 


\title{
An Expanded Three-Part Architecture for Post-2012 International Climate Policy
}

\author{
Sheila M. Olmstead \\ School of Forestry and Environmental Studies, Yale University \\ Resources for the Future \\ Robert N. Stavins \\ Harvard Kennedy School, Harvard University \\ Resources for the Future \\ National Bureau of Economic Research
}

Prepared for

The Harvard Project on International Climate Agreements 


\section{THE HARVARD PROJECT ON INTERNATIONAL CLIMATE AGREEMENTS}

The goal of the Harvard Project on International Climate Agreements is to help identify key design elements of a scientifically sound, economically rational, and politically pragmatic post-2012 international policy architecture for global climate change. It draws upon leading thinkers from academia, private industry, government, and non-governmental organizations from around the world to construct a small set of promising policy frameworks and then disseminate and discuss the design elements and frameworks with decision-makers. The Project is directed by Robert N. Stavins, Albert Pratt Professor of Business and Government, John F. Kennedy School of Government, Harvard University. For more information, see the Project's website: http://belfercenter.ksg.harvard.edu/climate

\section{Acknowledgements}

Major funding for the Harvard Project on International Climate Agreements has been provided by a grant from the Climate Change Initiative of the Doris Duke Charitable Foundation. Additional support has been provided by Christopher P. Kaneb (Harvard AB 1990); the James M. and Cathleen D. Stone Foundation; Paul Josefowitz (Harvard AB 1974, MBA 1977) and Nicholas Josefowitz (Harvard AB 2005); the Enel Endowment for Environmental Economics at Harvard University; the Belfer Center for Science and International Affairs at the Harvard Kennedy School; and the Mossavar-Rahmani Center for Business and Government at the Harvard Kennedy School.

\section{Citation Information}

Olmstead, Sheila and Robert Stavins. "An Expanded Three-Part Architecture for Post-2012 International Climate Policy” Discussion Paper 2009-29, Cambridge, Mass.: Harvard Project on International Climate Agreements, September 2009.

The views expressed in the Harvard Project on International Climate Agreements Discussion Paper Series are those of the author(s) and do not necessarily reflect those of the John F. Kennedy School of Government or of Harvard University. Discussion Papers have not undergone formal review and approval. Such papers are included in this series to elicit feedback and to encourage debate on important public policy challenges. Copyright belongs to the author(s). Papers may be downloaded for personal use only. 


\begin{abstract}
We describe the major features of a post-2012 international global climate policy architecture with three essential elements: a means to ensure that key industrialized and developing nations are involved in differentiated but meaningful ways; an emphasis on an extended time path of targets; and inclusion of flexible market-based policy instruments to keep costs down and facilitate international equity. This architecture is consistent with fundamental aspects of the science, economics, and politics of global climate change; addresses specific shortcomings of the Kyoto Protocol; and builds upon the foundation of the United Nations Framework Convention on Climate Change.
\end{abstract}

Key Words: global climate change, global warming, policy architecture, Kyoto Protocol

JEL Classification: Q54, Q58, Q48, Q39

Length: 12,000 words 


\title{
An Expanded Three-Part Architecture for Post-2012 International Climate Policy
}

\author{
Sheila M. Olmstead and Robert N. Stavins*
}

\section{INTRODUCTION}

The nations of the world continue to negotiate the post-2012 (or post-Kyoto) climate regime. This is happening, most centrally, through the United Nations Framework Convention on Climate Change (UNFCCC), which includes the Fifteenth Conference of the Parties (COP-15), scheduled for Copenhagen, Denmark, in December 2009. In addition, the key emitting countries of the world have been holding a series of meetings under the auspices of the Major Economies Forum, and a number of nations have been meeting in various other multilateral and bilateral venues. In all of these processes, the major goal is to develop international cooperation to address climate change when the first commitment period of the Kyoto Protocol expires at the end of 2012.

The Kyoto Protocol (United Nations 1997), which came into force in February 2005 and which began to bind for ratified countries in 2008, represents the first significant multinational attempt to curb the greenhouse gas emissions that are changing the global climate. ${ }^{1}$ The Protocol has both strengths and weaknesses that can provide lessons for the design of future international climate policy architecture. ${ }^{2}$

\subsection{Looking Back: The Kyoto Protocol's Strengths and Weaknesses}

Among the Kyoto Protocol's strengths is its inclusion of several provisions for market-based approaches intended to improve the cost-effectiveness of the global climate regime: emissions trading among Annex I countries ${ }^{3}$ that take on targets under the Protocol; "joint implementation” which allows for project-level trades among the Annex I countries; and the Clean Development Mechanism (CDM), which provides for the use of project-level emission offsets created in non-Annex I (developing) countries to help meet the compliance obligations of firms in Annex I countries.

\footnotetext{
*Olmstead is Associate Professor of Environmental Economics, School of Forestry and Environmental Studies, Yale University; and Visiting Scholar, Resources for the Future. Stavins is Albert Pratt Professor of Business and Government, John F. Kennedy School of Government, Harvard University; University Fellow, Resources for the Future; and Research Associate, National Bureau of Economic Research.
}

${ }^{1}$ Carbon dioxide $\left(\mathrm{CO}_{2}\right)$ is the primary anthropogenic driver of climate change. Other important anthropogenic greenhouse gases are methane $\left(\mathrm{CH}_{4}\right)$, nitrous oxide $\left(\mathrm{N}_{2} \mathrm{O}\right)$, and various halocarbons (Watson 2001).

${ }^{2}$ The general importance of focusing on policy "architecture" and institutions in the global climate domain was first emphasized by Schmalensee (1998).

${ }^{3}$ Annex I of the UNFCCC and Annex B of the Kyoto Protocol are often used interchangeably to represent the industrialized countries that have commitments under the Kyoto Protocol, although there are a few countries that are included in one Annex but not the other. 
A second advantage of the Kyoto Protocol is that it provides flexibility for nations to meet their national emissions targets - their commitments - in any way they want. In other words, the Protocol recognizes domestic sovereignty (in Article 2) by providing for flexibility at the national level. The political importance of this provision in terms of making it possible for a large number of nations to reach agreement should not be underestimated.

Third, the Kyoto Protocol has at least the appearance of fairness in that it focuses on the wealthiest countries and those responsible for the majority of the current stock of anthropogenic greenhouse gases in the atmosphere. This is consistent with the principle enunciated in the UNFCCC of "common but differentiated responsibilities and respective capabilities.”

Fourth and finally, the fact that the Kyoto Protocol was signed by more than 180 countries and subsequently ratified by a sufficient number of Annex I countries for it to come into force speaks to the political viability of the agreement in terms of participation, if not feasibility in terms of compliance.

The Kyoto Protocol also has some weaknesses that can provide valuable lessons for the path forward. First, some of the world's leading greenhouse gas emitters are not constrained by the Protocol. The United States - until recently the country with the largest share of global emissions — has not ratified and is unlikely to ratify the agreement. ${ }^{4}$ Also, some of the largest, most rapidly growing economies in the world do not take on targets under the agreement, including China, India, Brazil, South Africa, Indonesia, South Korea, and Mexico. The reality is that the developing world will soon overtake the industrialized world in total emissions. Indeed, China's $\mathrm{CO}_{2}$ emissions have surpassed those of the United States (Gregg et al. 2008); and China's emissions are expected to continue to grow much faster than U.S. emissions (Blanford, et al. 2008).

The anticipated growth paths of emissions in the various countries of the world clearly indicate that even if the Annex I countries, including the United States (that is, the currently industrialized countries) were to reduce their $\mathrm{CO}_{2}$ emissions to zero by 2020 to 2030, it would still be physically impossible for the world to achieve the frequently discussed climate target of stabilizing atmospheric $\mathrm{CO}_{2}$ concentrations at or below 450 parts per million (ppm). Furthermore, the Kyoto Protocol may not be as fair as originally intended, given how dramatically the world has changed since the UNFCCC divided countries into two categories in 1992. For example, approximately 50 non-Annex I countries now have higher per capita income than the poorest of the Annex I countries with commitments under Kyoto.

A second weakness of the Kyoto Protocol is the relatively small number of countries who have agreed to take action. This "narrow but deep" approach will drive up the costs of producing carbon-intensive goods and services within the coalition of countries taking action, which is fully appropriate as a means to reduce emissions. But through the forces of international trade, this approach also leads to greater comparative advantage in the production of carbon-intensive goods and services for countries that do not have binding emissions targets, thereby shifting production and emissions from participating nations to non-participating nations - a phenomenon known as

\footnotetext{
${ }^{4}$ Nonparticipation by the United States is quantitatively important, since it is responsible for approximately 19 percent of global $\mathrm{CO}_{2}$ emissions (Gregg et al. 2008).
} 
"emissions leakage.” Leakage will reduce the cost-effectiveness and environmental performance of the agreement, and worse yet, push developing countries onto more carbon-intensive growth paths than they would otherwise have taken, rendering it more difficult for these countries to join the coalition of action later.

A third concern about the Kyoto Protocol centers on the nature of its emissions trading elements. The provision in Article 17 for international emissions trading ${ }^{5}$ is unlikely to be effective, if indeed it is utilized at all, because the trading would need to be among national governments, not private-sector firms (Hahn and Stavins 1999). ${ }^{6}$ And there is great concern regarding the CDM, which is not a cap-and-trade mechanism, but an emissions-reduction-credit system, and thereby raises concerns about the "additionality" of generated offsets. ${ }^{7}$ In principle, this and related concerns could be addressed to some degree through future restructuring and reform of the CDM.

Fourth, the Kyoto Protocol, with its five-year time horizon (2008 to 2012), represents a relatively short-term approach for what is fundamentally a long-term problem. Greenhouse gases reside in the atmosphere for decades to centuries. Furthermore, to encourage the magnitude of technological change that will be required to meaningfully address the threat of climate change, it will be necessary to send long-term signals to the private market that stimulate sustained investment and technological innovation (Newell 2008).

Finally, the Kyoto Protocol may not provide sufficient incentives for countries to comply (Barrett 2008). Some countries' emissions have grown so fast since 1990 that it is difficult to imagine that they can undertake the emission mitigation or muster the political will and resources to purchase enough emission allowances or CDM credits from other countries to comply with their targets under the Protocol. In short, the enforcement mechanism negotiated for the Kyoto Protocol does not appear to induce policy responses consistent with agreed upon targets.

\footnotetext{
${ }^{5}$ The countries of the European Union (EU) have opted to use an emissions trading system (EU ETS), operating in pilot form from 2005 through 2007, and in earnest since 2008, to meet their emissions reduction targets, but that system is not part of the Article 17 trading system.

${ }^{6}$ The theory behind the claim that a cap-and-trade system will be cost effective depends upon the participants being cost-minimizing entities. In the case of private-sector firms, this is a reasonable assumption, because if firms do not seek, and indeed succeed in, minimizing their costs, they will tend to disappear, given the competitive forces of the market. But nation-states are not simple cost-minimizers - many other objectives affect their decision-making. Furthermore, even if nation-states sought to minimize costs, they do not have sufficient information about marginal abatement costs at the multitude of sources within their borders to carry out cost-effective trades with other countries (Hahn and Stavins 1999).

${ }^{7}$ When an individual project results in emissions below what they would have been in the absence of the project, a credit - which may be sold to a source within a cap-and-trade system - is generated. This approach creates a challenge: comparing actual emissions with what they would have been otherwise. The baseline - what would have happened had the project not been implemented — is fundamentally unobservable. In fact, there is a natural tendency, because of economic incentives, to claim credits precisely for those projects that are most profitable, and hence would have been most likely to have been executed without the promise of credits. This is the "additionality" problem.
} 


\subsection{Looking Forward}

Despite its strengths, because the Kyoto Protocol's ambitious targets apply only to the short term and only to some industrialized nations, the agreement imposes relatively high costs and generates minor short-term benefits, while failing to provide a real solution. Thus, some analysts see the agreement as “deeply flawed" (Victor 2001; Cooper 2001; McKibbin and Wilcoxen 2002, 2004). Others, however, see it as an acceptable or good first step (Grubb 2003; Michaelowa 2003). But virtually everyone agrees that the current framework is not sufficient to the overall challenge and that further steps will be required. ${ }^{8}$

Since the Kyoto Protocol was negotiated, scientific consensus regarding the likelihood of future climate change due to anthropogenic emissions of greenhouse gases has grown significantly (Watson 2001, Pachauri 2008). The 2007 Nobel Peace Prize, awarded to the Intergovernmental Panel on Climate Change (IPCC), has further focused public attention on the growing scientific consensus. Economic analysis increasingly points to the wisdom of policy action (Shogren and Toman 2000; Kolstad and Toman 2001; Nordhaus 2008a, 2008b). ${ }^{9}$ As Eileen Claussen, President of the Pew Center on Global Climate Change, wrote in 2003, "whether or not the Protocol enters into force, the same fundamental challenge remains: engaging all countries that are major emitters of greenhouse gases in a common long-term effort. We need a durable strategy that can take us beyond Kyoto" (Claussen 2003, p. ii).

The negotiation of a post-2012 global climate policy architecture, whether it builds on Kyoto or launches a fundamentally new approach, provides an opportunity to consider a significant dilemma. The Kyoto Protocol came into force without U.S. participation or meaningful participation by developing countries; its effects on climate change will be trivial; but the economic and scientific consensus points to the need for a credible international approach. ${ }^{10}$ What can be done? A reasonable starting point is the UNFCCC, which has been ratified by 193 countries - including the United States - and which entered into force in 1994. Among other things, the UNFCCC established the principle of "common but differentiated responsibilities," meaning that all nations should engage in the solution (because of the global-commons nature of the problem) but that different countries could participate in different ways (United Nations 1992). We offer a suggestion of a scientifically sound, economically rational, and politically pragmatic way forward.

\footnotetext{
${ }^{8}$ For a summary of critiques of the Kyoto Protocol and alternatives that have been proposed, see Aldy, Barrett and Stavins (2003). A comprehensive survey of proposals is provided by Bodansky (2004).

${ }^{9}$ Our claim that a consensus continues to form regarding the likelihood of future climate change due to anthropogenic emissions of greenhouse gases and regarding the desirability, from an economic perspective, of some long-term actions to address the threat does not suggest that there is unanimity either with regard to the science or the economics. See, for example, Lindzen (1992, 2008). In this paper, we simply take as given the desirability of limiting long-term concentrations of $\mathrm{CO}_{2}$ (and other greenhouse gases) in the atmosphere. For examinations of dynamically efficient policies (which maximize present value net benefits), see: Hammitt 1999; Nordhaus and Boyer 2000; and McKibbin and Wilcoxen 2002.

${ }^{10}$ Given the global commons nature of the climate problem, a multinational—if not fully global—approach is required. As long as global marginal benefits exceed every nation's own marginal benefits, countries will either want to avoid participating or avoid complying fully if they do participate. Successful international cooperation must change these incentives (Barrett and Stavins 2003).
} 


\section{A THREE-PART POLICY ARCHITECTURE}

Our proposal for a post-2012 international global climate policy agreement contains three essential elements: a means to ensure that key industrialized and developing nations are involved in meaningful ways; an emphasis on an extended time path of targets; and inclusion of the flexibility offered by market-based policy instruments. This architecture is consistent with fundamental aspects of the science, economics, and politics of global climate change.

\subsection{Expanding Participation}

The vast majority of the accumulated stock of anthropogenic $\mathrm{CO}_{2}$ in the Earth's atmosphere was emitted by sources in industrialized countries. Therefore, from the perspective of distributional equity, it can certainly be argued that industrialized countries should take serious actions to reduce their emissions before developing countries are asked to make their own contributions to such efforts. This is part of the thinking behind the "common but differentiated responsibilities" phrase in the UNFCCC, and it remains a forceful argument frequently made by a number of developing countries, most notably India (Toman, Chakravorty, and Gupta 2003).

It is ironic that distributional equity might therefore favor a relatively narrow coalition of action, like that embodied in the Annex I list. It is equally ironic that efficiency, or more accurately, cost-effectiveness, favors a broader coalition of action. This is because the criteria of efficiency and cost-effectiveness focus on the margin, that is, are forward-looking. Indeed, broad participation by major industrialized nations and key developing countries — is essential to address this global commons problem effectively and efficiently.

\subsubsection{Four Reasons for Employing a Broad Set of Participants}

The share of global emissions attributable to developing countries is significant and growing rapidly. China surpassed the United States as the world's largest emitter of $\mathrm{CO}_{2}$ in 2006. The rate of growth in China's emissions is even more important: China emitted 8 percent of global anthropogenic $\mathrm{CO}_{2}$ in 1981, 14 percent in 2002, and about 21 percent by 2008 (Gregg et al. 2008). ${ }^{11}$ More broadly, developing countries are likely to account for more than half of global emissions by the year 2020, if not before (Nakicenovic and Swart 2000; Pies and Schröder 2002). ${ }^{12}$

In addition to being an important and growing source of emissions, developing countries also provide the greatest opportunities for relatively low-cost emissions reductions (Watson 2001). It would therefore be unnecessarily costly to focus emissions-reductions activities exclusively in the developed world. Inclusion of key developing countries in a future climate regime can reduce overall costs dramatically. According to one estimate, achieving the Kyoto Protocol's emissions

\footnotetext{
${ }^{11}$ About one-half of the significant growth in China's $\mathrm{CO}_{2}$ emissions in the early part of this decade is attributable to export growth, one-third to capital formation, and most of the rest to consumption by households and government institutions (Guan et al. 2009). Some of these trends may have slowed due to the global recession in 2008-2009.

12 Non-OECD countries accounted for 53 percent of energy-related $\mathrm{CO}_{2}$ emissions by 2006, and are expected to surpass 60 percent of energy-related $\mathrm{CO}_{2}$ emissions by 2020 (U.S. Energy Information Administration 2009).
} 
targets using a system of international tradable permits — if implemented only for the industrialized countries (as in the Kyoto Protocol) - could reduce costs by 50 percent, but if such a system were to include major developing countries as well, costs could be lowered to 25 percent of what they otherwise would be (Edmonds et al. 1997).

There is a third reason to ensure that a post-2012 international climate policy architecture includes key developing countries. The United States and several other industrialized countries have signaled their unwillingness to commit to significant emissions reductions without their participation. For example, in the months leading up to Kyoto, the U.S. Senate voted 95-0 in support of the Byrd-Hagel resolution, which stated that the United States should not approve any agreement in Kyoto that did not impose binding emission reduction targets on major developing countries, as well as industrialized nations. More recently, the G8 countries declared after a July 2008 meeting in Hokkaido, Japan that "all major economies" should contribute to a target of reducing global emissions 50 percent (from an unspecified base) by 2050, code words for their desire to include countries such as China and India in any formal compact (Agarwala 2008). ${ }^{13}$

The United States must be involved in any meaningful post-2012 architecture. It is the world's second-largest emitter and the largest historical contributor to the current stock of greenhouse gases in the atmosphere. But without broad-based global participation, meaningful participation by the United States is unlikely. Other industrialized countries may also be willing to agree to more stringent cuts in emissions if the United States, China, and other parties who did not take on targets in the Kyoto Protocol are included in a post-2012 architecture. ${ }^{14}$

A fourth reason to include developing countries in a post-2012 global climate policy architecture is to ensure the environmental effectiveness of emissions reductions by participating countries. If developing countries are not included in an agreement, comparative advantage in the production of carbon-intensive goods and services may shift outside the coalition of participating countries, making developing countries' economies more carbon intensive than they otherwise would be, through emissions leakage.

Estimates from computable general equilibrium models of potential carbon leakage rates under a global climate regime range from 5 percent to 34 percent (Paltsev 2001). ${ }^{15}$ High leakage rates would erase environmental gains from emissions reductions by participating countries. Rather than helping developing countries move onto less carbon-intensive paths of development, the

\footnotetext{
${ }^{13}$ In July 2009, the major developing country emitters rejected a proposal to reduce global emissions 50 percent by 2050 (again, from an unspecified base), though industrialized countries would have cut their own emissions by 80 percent to further that goal, under the agreement.

${ }^{14}$ For example, EU countries suggested during a meeting of the European Council in Brussels in 2008 that they would cut emissions more significantly (30 percent below 1990 levels, rather than 20 percent below 1990 levels by 2020) if other countries made commitments to larger reductions.

${ }^{15}$ Models also suggest that international emissions trading could decrease these estimated carbon leakage rates by about one-half (Paltsev 2001).
} 
industrialized world would be pushing those nations onto more carbon-intensive growth paths, increasing their cost of joining the coalition later. ${ }^{16}$

Some have argued that because current differences in carbon costs between the United States (where there are voluntary and mandatory regional markets) and Europe (in the EU Emissions Trading System) have not affected industrial location decisions, leakage is not a key concern for future international climate policy (Victor 2007). However, it is simply too early to judge the effects of European and American emissions policies in this regard. Meaningful carbon trading in the European Union did not begin until January 2008. Trading began in the largest regional market in the United States, the Regional Greenhouse Gas Initiative (RGGI), in 2009. ${ }^{17}$ The extent to which differences in EU-US carbon costs will affect trade flows and carbon intensity depends on expected prices over the next 10 or 20 years for firms considering long-lived capital investments. It would be a mistake to conclude that because visible leakage has not yet occurred among wealthy countries that it will be an unimportant phenomenon under future climate policy scenarios.

\subsubsection{Cost-Effectiveness and Distributional Equity}

If a post-2012 international climate policy architecture is to be meaningful, the large and rapidly-growing developing countries must be involved, due to the magnitude of their current emissions, their expected rates of growth in emissions, their lower costs of emissions reductions, the increased likelihood of U.S. participation and willingness by other industrialized countries to engage in deeper emissions reductions, and the possibility of carbon leakage. However, on equity grounds, it is not reasonable to expect developing nations to incur significant emissions-reduction costs in the short term, because it would slow their economic development. And it can surely be argued on an ethical basis that industrialized countries should take the first emission-reduction steps on their own. Industrialized countries — almost by definition — are responsible for the bulk of anthropogenicbased concentrations of greenhouse gases in the atmosphere.

This poses a policy conundrum. On the one hand, for purposes of environmental performance and cost effectiveness, key developing countries must participate in an international effort to reduce greenhouse gas emissions, but on the other hand, for purposes of distributional equity (and international political pragmatism ${ }^{18}$ ), they cannot be expected to incur the brunt of the

\footnotetext{
${ }^{16}$ Comprehensive studies through the mid-1990s found little or no evidence of impacts of environmental regulations on trade patterns, although the same studies established that such regulations were costly (Jaffe et al. 1995, Levinson 1996). Subsequent analyses established empirical evidence for the phenomenon, but for environmental regulations outside of the climate realm. Tests of the theory are complicated by unobservable heterogeneity and endogeneity (Brunnermeier and Levinson 2004). This is because unobserved industry and country traits can be correlated with the likelihood of regulation and the export of pollution-intensive goods. Environmental regulation often appears in high-income countries with substantial international trade, but does trade influence pollution regulation or vice-versa? Recent studies have established that polluting industries may be exported where trade is between high and low-standard countries, and industries are particularly mobile (Ederington et al. 2005).

${ }^{17}$ We consider the European cap-and-trade system and RGGI in more detail below.

${ }^{18}$ International agreements under the United Nations are approved on the basis of one country, one vote; and developing countries greatly outnumber industrialized nations.
} 
consequent costs. The solution is that these countries must get on the "global climate policy train" without necessarily paying full fare. How can this be accomplished? ${ }^{19}$

Achieving developing country participation may require a trigger mechanism, imposing binding commitments only when per capita income, emissions per capita, or some other measure of development has reached a predetermined level. But there is no reason to limit thinking to such a simple, dichotomous instrument. Rather, a preferable approach would be continuous "growth targets” that become more stringent for individual developing counties as those countries become more wealthy (Lutter 2000).

A growth target is not a number, but an equation or set of equations that relate targeted emissions to per-capita income and other variables. Two necessary characteristics of a growth target formulation are that it not create perverse incentives that would encourage nations to increase their emissions and that it should be relatively simple, so as not to create impediments to negotiation (Aldy, Baron, and Tubiana 2003).

This is a natural extension of the progressive target allocation present in the Kyoto Protocol. The extension is from the industrialized world to the developing world, and from the cross-sectional dimension to the temporal dimension. The Kyoto Protocol's targets exhibit positive correlation between national wealth (in particular, gross domestic product - GDP — per capita) and the degree of targeted emissions reduction. In fact, the Kyoto targets exhibit an "income elasticity of reductions" of about 0.14 , that is, for a 10 percent increase in per-capita GDP, the targets - on average - are about 1.4 percent more stringent (Frankel 1999, 2005). Though this was not a formal goal of the Kyoto Protocol (the positive income elasticity can simply be observed in the Protocol's negotiated targets), a post-2012 international climate architecture could incorporate specific formulas ex ante for increasing developing country participation over time.

\subsubsection{A Formulaic Approach to Allocating Responsibility}

Specific emissions targets for all countries, and for each five-year period remaining in this century, could emerge from a formula that would generate targets based on three elements: shortterm progressivity, latecomer catch-up, and equalization, while constraining targets so as not to impose costs over the century exceeding an average of 1 percent of GDP per year, or 5 percent of GDP for any country in any period (Frankel 2008). ${ }^{20}$ The "short-term progressivity" factor would adjust emissions targets based upon per capita income (applying the income elasticity of reductions implied by the Kyoto targets). "Latecomer catch-up” avoids rewarding countries that failed to curb their emissions after 1990 (the Kyoto baseline year). This would include countries such as Canada, which ratified the Protocol, but is unlikely to comply; countries such as the United States, which did not ratify the agreement; and countries such as China, which did not take on targets at Kyoto. This would help close the gap between 1990 emissions and the starting points of latecomers to the

\footnotetext{
${ }^{19}$ For perspectives from three key developing countries — China, India, and Brazil — see Longhai (2008), Parikh (2008), and Reis (2005). Also, see: Agarwala (2008), Cao (2008), Garnaut, Song, and Woo (2009), Somanathan (2008), and Teng et al. (2008).

${ }^{20}$ Game-theoretic analyses suggest that the use of formulas can render negotiations more likely to succeed (Harstad 2008).
} 
process. Finally, the "equalization factor" would move all countries in the direction of global average per capita emissions in the second half of the century, asking rich countries to make up, somewhat, for the fact that they previously enjoyed the benefits of unfettered $\mathrm{CO}_{2}$ emissions, creating an environmental problem for which poor countries bear disproportionate impacts (Frankel 2008).

In the short term, such indexed targets for major developing countries could be set at business-as-usual (BAU) emissions levels, but they would become more stringent over time as the countries became wealthier. In Frankel's (2008) proposal, for example, China's emissions target would be equivalent to BAU emissions until 2040, slightly below BAU between 2040 and 2045, and then it would begin to drop. The smaller East Asian countries and Sub-Saharan Africa would have targets equal to BAU for the remainder of the century. Keeping even poor countries at or near BAU emissions is an important goal, since it prevents the possibility of significant carbon leakage.

If provision is not made for such a mechanism that includes developing countries at low or no cost to them, then analysis inevitably points to a trade-off between cost-effectiveness (or efficiency) and distributional equity (Sugiyama and Deshun 2004). Thus, such a mechanism will likely be necessary to induce meaningful developing country participation. If emissions targets at BAU for the short- to medium-run (or even the long run for some regions) were combined with an appropriate international trading program (discussed below), this could provide a direct economic incentive (subsidy) for developing-country participation. Developing countries could fully participate without incurring prohibitive costs (or even any costs in the short term). That is, costeffectiveness and distributional equity could both be addressed. ${ }^{21}$

\subsection{An Extended Time Path of Targets}

Global climate change is a long-term problem, due to the fact that the relevant greenhouse gases remain in the atmosphere for decades to centuries, combined with the reality that significant technological change will be required to bring down costs to levels where greater actions can be taken. The Kyoto Protocol fails to reflect these fundamentally important realities with its short-term targets, an average 5 percent reduction from 1990 levels by the 2008-2012 "first commitment period.” This apparently modest reduction translates into a severe 25-30 percent cut for the United States from its BAU emissions path. The reason for this is that the United States economy grew at an exceptionally rapid rate during the 1990s, exhibiting a remarkable 37 percent increase in real GDP from 1990 to $2000 .^{22}$

\footnotetext{
${ }^{21}$ For other approaches to engaging developing countries, such as ones that emphasize integrating development objectives with global climate policy objectives, see: Agarwala (2008), Cao (2008), Hall, Pizer, Levi, and Ueno (2008), Heller and Shukla (2003), Keeler and Thompson (2008), Somanathan (2008), Teng et al. (2008), and Victor (2008).

${ }^{22}$ This contrasts dramatically with the situation in Europe and elsewhere, where economies were stagnant or grew much more slowly. Furthermore, emissions of $\mathrm{CO}_{2}$ from the United Kingdom, Germany, and Russia fell significantly subsequent to 1990 (the Kyoto Protocol's baseline year) for reasons having nothing to do with climate or other environmental policy. Emissions fell in the United Kingdom because of structural changes in the domestic coal industry initiated by Prime Minister Margaret Thatcher's government (1979-1990); emissions fell in Germany because reunification led to the closure of energy-inefficient plants in the former East Germany; and emissions fell in Russia because of its economic collapse in the 1990s (McKibbin and Wilcoxen 2002). Importantly, it has been estimated that 80 percent of the European Union's $\mathrm{CO}_{2}$ reductions under the Kyoto Protocol would be achieved by two countries -
} 
Thus, the Kyoto Protocol's targets seek to achieve "too little, too fast:” They do little about the problem, but are unreasonable for countries that enjoyed significant economic growth after 1990. Two elements can ameliorate this problem: firm but moderate targets in the short term to avoid rendering large parts of the capital stock prematurely obsolete, and flexible but considerably more stringent targets for the long term to motivate (now and in the future) technological change, which in turn is needed to bring costs down over time (Goulder and Schneider 1999; Jaffe, Newell, and Stavins 1999; Pershing and Tudela 2003; Newell 2008). Specifically, emissions targets ought to start out at BAU levels, and then gradually depart from BAU levels. Globally, these intertemporal emissions targets should not be monotonically increasing, but should reach a maximum level and then begin to decrease - eventually becoming substantially more severe than the constraints implied by the Kyoto Protocol's short-term targets. ${ }^{23}$

Precise, numerical emissions targets for long time horizons, if they are inflexible, are impractical due to uncertainty over future growth, technological change, and the science of climate change and its effects. Some of the considerable uncertainty throughout the policyeconomics-biophysical system will be resolved over time (Richels, Manne, and Wigley 2004, Mendelsohn 2008). Thus, long-term targets must retain some flexibility; the emissions target formulas proposed by Frankel (2008) are a good example.

In addition, since long-run emissions targets require that current leaders (especially elected officials) bind future political leaders to costly commitments, many have pointed out that long-term targets are dynamically inconsistent and must incorporate constraints representing the economic reality that no country is likely to abide by an unenforceable international agreement that causes great economic disruption in any particular year, or set of years (Frankel 2008). ${ }^{24}$

The pattern we suggest is consistent with estimates of the least-cost time path of emissions for achieving long-term greenhouse-gas concentration targets: short-term increases in emissions just slightly below the BAU path — and subsequent emission reductions (Wigley, Richels, and Edmonds 1996; Manne and Richels 1997). ${ }^{25}$

Germany and the United Kingdom, facilitated via the EU bubble that is part of the Protocol (Andersen 2002). These factors help explain the very different perspectives on the Kyoto Protocol held by Europeans and Americans, although other, broader phenomena are also at work (Kagan 2002).

${ }^{23}$ For a broader survey of the relationship between technological change and the environment, see Jaffe, Newell, and Stavins (2003). For an analysis of the implications of combining such an intertemporal pattern of targets with gradual expansion of the coalition of nations that take on targets, see den Elzen (2002).

\footnotetext{
${ }^{24}$ The word "target" should be taken generically to refer not only to emission targets (as in the Kyoto Protocol, and as described above), but also "intensity targets," that is, emissions per unit of gross domestic product. For that matter, the proposal we offer here is also consistent with a time-path of targets denominated in purely financial units, that is, carbon prices implemented through taxes on the carbon content of fossil fuels (Cooper 2008).

${ }^{25}$ For the global goal of stabilizing atmospheric concentrations of $\mathrm{CO}_{2}$ at twice pre-industrial levels (that is, approximately 550 parts per million), Wigley, Richels, and Edmonds (1996) estimated that the cost-effective time path of emissions would involve global emissions peaking in 2030. For stabilization of $\mathrm{CO}_{2}$ at $450 \mathrm{ppm}$, the general shape of trajectories remains, but it is necessary for global emissions to peak and begin to decrease much sooner. The recommended intertemporal pattern of emissions targets is also consistent with recommendations for the use of "intensity targets," as highlighted in the United States by the National Commission on Energy Policy (2004).
} 
Such a time path of long-term targets, put in place now, would be consistent with what is often denigrated as "politics as usual." That is, politicians are frequently condemned for the fact that in representative democracies there are strong incentives to place costs on future, not current, voters and, if possible, future generations. It is typically the politically pragmatic strategy. In the case of global climate policy, it can also be the scientifically correct and economically rational approach. Frankel points out that his "politically feasible" proposal of emissions target formulas implies a similar time path of emissions reductions (and carbon prices) as the benefit-cost paths proposed by economic models — small cuts now, big cuts later (2008).

\subsection{Market-Based Policy Instruments}

The final component of the three-part policy architecture we propose is necessary to achieve global cost-effectiveness and thereby to render the overall architecture politically achievable: working through the market rather than against it. There is widespread agreement that conventional regulatory approaches cannot do the job, certainly not at acceptable costs. To keep costs down in the short term and bring them down even lower in the long term through technological change, it is essential to embrace market-based instruments as the chief means of reducing greenhouse gas emissions (Stavins 1997; Lackner 2005; Metcalf 2009).

On a domestic level in some countries, systems of tradable permits — otherwise known as “cap-and-trade" — might be used to achieve national targets. In an emissions permit-trading system, sources that have low costs of control have an incentive to take on added reductions, so that they can sell their excess permits to sources that face relatively high control costs and would hence wish to reduce their control efforts (Hockenstein, Stavins, and Whitehead 1997). This is the same mechanism that was used in the United States to eliminate leaded gasoline from the market in the 1980s at a savings of more than $\$ 250$ million per year (Stavins 2003), and the same mechanism being used to cut sulfur dioxide $\left(\mathrm{SO}_{2}\right)$ emissions from power plants in the United States by 50 percent, at a savings estimated to be $\$ 1$ billion per year (Schmalensee, et al. 1998; Stavins 1998; Ellerman, et al. 2000). Of the two systems, the better model for climate change policy is the upstream lead-rights system (analogous to trading based on the carbon content of fossil fuels), rather than the downstream $\mathrm{SO}_{2}$ emissions-trading system. ${ }^{26}$

For some countries, systems of domestic carbon taxes may be more attractive than cap-andtrade approaches. ${ }^{27}$ Rather than imposing a cap on the quantity of pollution, and allowing regulated firms to trade emissions permits to establish a market price for pollution, a tax imposes a specific price on pollution and allows firms to decide how much to pollute in response. A tax has an effect on firms' decisions that is essentially identical to the effect of the permit price created by a cap-and-trade policy; polluters decide, for each ton of emissions, whether to abate that ton (incurring the resulting abatement costs) or to pay the tax and continue to emit that ton. Domestic carbon taxes

- typically in the form of upstream taxes on the carbon content of fossil fuels - have frequently

\footnotetext{
${ }^{26}$ It is not necessary that the (upstream) level of compliance be the same as the (possibly downstream) level of initial allocation. There are also two regional U.S. tradable permit markets for nitrogen oxides (NOx) in southern California and the northeast and mid-Atlantic states, created primarily to reduce concentrations of ground-level ozone.

${ }^{27}$ Norway introduced a carbon tax in 1991. Despite its considerable magnitude and consequent induced increases in fuel prices, impacts on $\mathrm{CO}_{2}$ emissions were modest, in part because of extensive tax exemptions (Bruvoll and Larsen 2004).
} 
been recommended by academics (Metcalf 2007; Metcalf and Weisbach 2009), ${ }^{28}$ but have received considerably less support in the policy community.

Another promising market-based approach is a hybrid of tax and tradable-permit systems that is, an ordinary cap-and-trade system, plus a government promise to sell additional permits at a stated price (Roberts and Spence 1976; Kopp, et al. 2000; Pizer 2002; McKibbin and Wilcoxen 2002). This creates a price (and thereby cost) ceiling, and has hence been labeled a safety-valve system. $^{29}$ Likewise, a price floor can be created by a government promise to purchase allowances from the market at a given price. The combination of the two approaches - known as a "price collar” - may have particular merit in the climate context (Murray, Newell, and Pizer 2009).

Among these alternative market-based policy instruments, the one which is emerging as the preferred approach among industrialized countries is the particular version of emissions trading known as cap-and-trade (Jaffe and Stavins 2008). At the same time, the emission-reduction credit system created under the Kyoto Protocol - the Clean Development Mechanism - enjoys a solid constituency of support in the developing world (Somanathan 2008).

\subsubsection{The Promise and Problems of International Emissions Trading}

The Kyoto Protocol includes in Article 17 a system whereby the parties to the agreement can engage in trading their "assigned amounts," that is, their reduction targets, translated into quantitative terms of emissions (United Nations 1997). In theory, such a system of international tradable permits - if implemented only for the industrialized countries (as under the Kyoto Protocol) - could reduce costs by 50 percent. If such a system also included major developing countries, costs could be lowered to 25 percent of what they otherwise would be (Edmonds et al. 1997).

An undisputed attraction - in theory - of an international trading approach is that the equilibrium allocation of permits, the market-determined permit price, and the aggregate costs of abatement are independent of the initial allocation of permits among countries. However, this is only true as long as particularly perverse types of transaction costs are not prevalent (Stavins 1995) and individual parties — be they nations or firms — do not have market power (Hahn 1984). The latter concern is a real one in the Kyoto context. ${ }^{30}$ In any event, the initial allocation can be highly significant in distributional terms, implying possibly massive international wealth transfers. Some analysts have highlighted this as a major objection to an international carbon trading regime (Cooper

\footnotetext{
${ }^{28}$ Others have argued in favor of an international tax regime. See, for example: Cooper (1998, 2008); McKibbin and Wilcoxen (2002); Pizer (2002); Newell and Pizer (2003); and Nordhaus (2008a).

${ }^{29}$ For a description of the origin and evolution of the concept in climate policy deliberations, an assessment of its potential application as a domestic policy instrument, and an evaluation of potential problems it would present if adopted as an international policy instrument, see Jacoby and Ellerman (2004).

${ }^{30}$ Currently, the majority of excess permits (allowable emissions in excess of BAU emissions, or so-called ?hot air?) is found in a relatively small number of nations in Central and Eastern Europe and the former Soviet Union, since Kyoto's 1990 baseline failed to account for substantially reduced industrial activity in these countries after the collapse of the Soviet Union. Some have pointed out that the possibility of collusion in a permit market among such a small number of potential sellers becomes quite likely (Manne and Richels 2004; Springer and Varilek 2004).
} 
1998, 2008), but it is essentially because of this feature that a permit system can be used to address cost-effectiveness and distributional equity.

If an international trading system is used, it must be designed to facilitate integration with domestic policies that nations use to achieve their respective domestic targets. ${ }^{31}$ In the extreme, if all countries use domestic tradable permit systems to meet their national targets (that is, allocate shares from the international permit system to private domestic parties), then an international system can - in theory - be perfectly cost-effective. But if some countries use non-trading approaches, such as greenhouse gas taxes or fixed-quantity standards - which seems likely — cost minimization is not ensured (Hahn and Stavins 1999). ${ }^{32}$ Thus, individual nations' choices of domestic policy instruments to meet their targets can substantially limit the cost-saving potential of an international trading program. In this realm, a trade-off exists between the degree of domestic sovereignty and the degree of cost-effectiveness. An emerging answer, which we discuss below, may be the linkage of independent domestic and regional cap-and-trade systems, thereby facilitating cost-effective trades among individual sources (firms), both domestically and internationally.

\subsubsection{The European Union Emissions Trading Scheme}

Not very long ago, most observers would have predicted that few, if any, European countries would employ cap-and-trade systems, given the European Union's strenuous opposition to such approaches dating to back to the time of the Kyoto Protocol. But after some initial flirtations with carbon tax considerations, the EU launched a continent-wide trading system - the largest existing international cap-and-trade system for $\mathrm{CO}_{2}$ - to meet its emissions reduction targets under the Protocol (Kruger and Pizer 2004).

The Kyoto Protocol establishes a bubble for the European Union, that is, it sets a cap on $\mathrm{CO}_{2}$ emissions for the EU as a whole, allocated by the EU to it member states. Under this cap, the European Union Emissions Trading Scheme (EU ETS) was established in 2005, and after a pilot phase, entered its more meaningful Kyoto phase in January 2008.

The EU ETS is now the world's largest emissions trading system, covering almost 12,000 facilities in 27 countries as of 2008, and accounting for nearly one-half of $\mathrm{EU} \mathrm{CO}_{2}$ emissions (Ellerman and Buchner 2007, Ellerman and Joskow 2008, Ellerman 2008, Convery and Redmond 2007). The Kyoto Protocol's emissions caps did not begin to bind until 2008, so the pilot phase of the EU ETS (2005-2007) was designed to set up the institutional and operating structures necessary for trading. The cap in the EU system in this pilot phase was a very small reduction (a few percentage points) below expected emissions in the absence of the policy. Given that the system was designed not to begin to bind in meaningful ways until 2008, which turned out to be a time of global recession (and hence falling $\mathrm{CO}_{2}$ emissions), it is much too soon to determine with

\footnotetext{
${ }^{31}$ Note that the Kyoto Protocol explicitly provides for national sovereignty regarding domestic instrument choice in Article 2. This might be a necessary element of a future, politically viable international agreement.

${ }^{32}$ In such cases, achieving the potential cost savings of international trading would require some form of project-byproject credit program, such as the Kyoto Protocol's Clean Development Mechanism(CDM). But theory and experience with such programs indicates they are less likely to facilitate major cost savings because of large transaction costs, government participation, and the absence of well-functioning markets (Michaelowa, et al. 2003).
} 
any reliability the impact of this new carbon market on emissions, or the cost savings from the EU ETS over more prescriptive approaches.

Some see the EU ETS as a prototype for a post-2012 international global climate regime, noting that the 30 states involved constitute an increasingly diverse set of sovereign countries; for example, per capita income in Romania and Bulgaria, who joined upon EU accession in 2007, is only one-third more than per capita income in China; and per capita income in Ireland is five percent higher than in the United States (Ellerman 2008). Many of the problems encountered and addressed by the EU ETS may be similar to those a fully international trading architecture would encounter.

The EU ETS has not been without its conflicts. Nine of the ten East European countries have sued the European Commission over their allotted emissions caps for 2008-2012. But the"club benefits" of continued membership in the European Union, including free labor and capital flows and access to broader markets, have apparently outweighed the costs of the EU ETS for these poorer nations, as they have chosen to remain within the system, rather than dropping out (Ellerman 2008).

\subsubsection{The Emergence of Climate Cap-and-Trade Systems in the United States}

Several domestic tradable permit systems for $\mathrm{CO}_{2}$ are in place in the United States. Although the U.S. government (Senate) did not ratify the Kyoto Protocol, some states have enacted policies to reduce their greenhouse gas emissions. The largest U.S. market-based initiative is the Regional Greenhouse Gas Initiative (RGGI), a cap-and-trade system among 10 northeastern states, initiated in 2003. The trading program covers electricity generators within the 10 states and began in earnest in 2009. Allowances under RGGI are auctioned, and firms trade allowances and various financial derivatives (including futures and options contracts) in a secondary market. Trading in the secondary market was active during the first quarter of 2009 (Potomac Economics 2009). The RGGI $\mathrm{CO}_{2}$ emissions cap for 2009-2014 roughly equals the sum of recent emissions among covered generators, then declines by 2.5 percent per year from 2015 through 2018. In 2008, the State of California took a serious step toward establishing its own cap-and-trade system for energy-related $\mathrm{CO}_{2}$ emissions to meet a target of achieving emissions in 2020 equal to those in 1990, a goal established by state law in 2006 (Jaffe and Stavins 2008).

In June 2009, the Federal government in the United States took its most significant steps to date toward putting in place a national cap-and-trade policy to reduce $\mathrm{CO}_{2}$ emissions, with the passage in the House of Representatives of the American Clean Energy and Security Act, also known as the Waxman-Markey bill, named for the two Members of Congress who co-sponsored the bill. This legislation would cap national greenhouse gas emissions by nearly all significant sources, including coal-fired power plants, factories, natural gas suppliers, and fuels, setting up a cap-andtrade system to achieve emissions reductions. If similar legislation is passed by the U.S. Senate, the emissions cap would be phased in over several years for various sectors. The target reductions for covered sources in the bill amount to 17 percent cuts below 2005 levels by 2020, and progressively steeper cuts as time goes on (42 percent by 2030, and 83 percent by 2050).

\subsubsection{Linking National and Regional Cap-and-Trade Systems}

In addition to the nations of the European Union and the United States, a number of other major countries in the industrialized world are currently considering the adoption of national cap- 
and-trade systems to reduce $\mathrm{CO}_{2}$ emissions, including Australia, Canada, Japan, and New Zealand (Jaffe and Stavins 2008). The increasing number of existing, planned, and proposed regional, national, and sub-national cap-and-trade policies for $\mathrm{CO}_{2}$ emissions reduction raises the possibility, indeed, the probability, that the linkage of these systems will constitute a significant element of the a future international climate policy architecture. In this context, linkage refers to the recognition of the allowances (permits) from one system for use in meeting compliance requirements in another. The potential benefits of such linkage of domestic systems include cost savings from increasing the scope of the market, greater market liquidity, reduced price volatility, lessened market power, and reduced carbon leakage (Jaffe and Stavins 2008). ${ }^{33}$

There are several ways in which international linkage could occur. Domestic cap-and-trade programs could be linked directly, either unilaterally or bilaterally. With a direct bilateral linkage, both domestic cap-and-trade policies would recognize allowances from the other system toward the emissions caps of permitted entities (firms and/or plants). Unilateral linkages may arise in which one system recognizes allowances from the other, but the recognition is not mutual. Allowance prices would converge with direct bilateral linkage, so long as there were no constraints on intersystem trades, and with unilateral linkage as long as the buying system's price was higher than the selling system's price - no trading would take place if the opposite were true (Jaffe and Stavins 2008).

A potential problem is that direct linkage of cap-and-trade systems will lead to the automatic transmission of cost-containment elements - banking, borrowing, safety valves, and price collars - from one system to the other. This raises concerns for some countries, because of the possible loss of control of their domestic systems, and raises the possibility that systems would need to be harmonized in advance of linkage, so that such undesirable outcomes would be prevented.

Importantly, this necessity for prior harmonization can be eliminated through the substitution of indirect links for direct ones. In particular, if each of a number of cap-and-trade systems link with a common emission-reduction credit system, then all of the cap-and-trade systems will be linked (indirectly), achieving the benefits of cost reduction, greater market liquidity, reduced price volatility, lessened market power, and reduced carbon leakage, but without the unintentional transmission of cost-containment mechanisms from one system to another, thereby reducing, if not eliminating the need for prior harmonization.

In theory, if a cap-and-trade system is linked with a credit system, prices will converge in the two systems. And prices in two cap-and-trade systems which are indirectly linked will also converge, as credits flow to the system with the highest price (Jaffe and Stavins 2008). With a sufficient supply of credits, prices in all systems will converge, though this may not occur if binding constraints are imposed on the use of credits and allowances from other systems.

This is a rather good description of what appears to be evolving, that is, the emergence of regional and national cap-and-trade systems in the industrialized world, each of which allows offsets

\footnotetext{
${ }^{33}$ Such linkage of domestic cap-and-trade systems is initiated by agreements between respective governments, but importantly — it leads to trading not among governments, but among firms within the respective countries. This circumvents the problems inherent in Article 17 of the Kyoto Protocol for international emissions trading, which as we emphasized earlier is unlikely to be effective, if indeed it is utilized at all (Hahn and Stavins 1999)
} 
to some degree from the Clean Development Mechanism (CDM), the emission-reduction credit system in developing countries that was established under the Kyoto Protocol. When a cap-andtrade system is linked with the CDM, tradable credits are awarded to a buyer (which may face a mandatory cap on emissions) for certified (but voluntary) emissions reductions by another party. Under the CDM, certified emissions reductions (CERs) are awarded for voluntary emission reduction projects in developing countries that ratified the Kyoto Protocol, but are not among the countries subject to emissions limitations. The industrialized countries that did take on emissions targets under the Protocol can use CERs to meet these commitments. ${ }^{34}$

The CDM has begun to be linked with multiple cap-and-trade systems; CERs can be used to meet emissions commitments within the EU-ETS, and RGGI, under some circumstances. It is too early, however, to assess the impact of these linkages on allowance (or credit) prices, trading, and emissions in the EU ETS-RGGI-CDM markets, because the EU ETS began in earnest only in 2008 and RGGI in 2009.

A potential concern associated with linking cap-and-trade systems through a common emission-reduction credit systems is "additionality" - credit systems, including the CDM, have been plagued by questions about the actual emissions reductions represented by credits, because of the difficulty of establishing a baseline against which reductions can be measured. Linking credit systems with cap-and-trade system passes this worry along to the latter system, in which it would otherwise not be a significant concern. Thus, there is something of a trade-off between the potential economic and environmental gains of such a bottom-up system of global indirect linkage, on the one hand, and the potential economic and environmental losses that such linkage can bring about if additionality problems are severe. ${ }^{35}$

\subsubsection{The Role of Emissions Trading in a Future International Climate Policy Architecture}

One of the key objections to the efficacy of a post-2012 international climate policy architecture with international emissions trading as a core element is that industrialized countries will not support such a policy, once the cross-border financial flows implied by trading allocations that favor developing countries (in order to prompt their accession to the agreement) become apparent (Victor 2007, Cooper 1998). However, despite the significant variation in per capita income across EU ETS member states, which has grown over time as an increasing number of poorer states have joined, this has not turned out to be a point of controversy (Ellerman 2008). This may be due to the fact that, while trading is active, financial flows from emissions trading represent a very small portion of total imports and exports. ${ }^{36}$

\footnotetext{
${ }^{34}$ Analysts expect that the CDM will have generated more than 2.7 billion CERs by the end of 2012, the majority of them for projects in China, with each CER representing an emissions reduction of one metric ton of $\mathrm{CO}_{2}$ equivalent (Jaffe and Stavins 2008).

${ }^{35}$ Other concerns include: distributional consequences of raising prices in some systems and lowering them in others; capital flows between regions and countries; reduction of control over domestic tradable permit system design; and incentives in setting future caps in these disparate systems.

${ }^{36}$ For example, the United Kingdom is the largest emissions allowance importer in the ETS, importing 14 percent of its verified emissions, worth about $£ 350$ million. But this still represents a very small portion - less than one-tenth of one percent - of its total imports of goods and services, about $£ 415$ billion (Ellerman 2008).
} 
In addition, any viable alternative that engages the major developing countries in an international climate policy architecture will likely involve some form of financial transfers from industrialized to developing countries. Critics of the financial flows implied by permit allocations skewed toward developing countries have suggested that industrialized countries engage developing countries by making direct financial contributions for the implementation of climate-friendly policies that these countries support, such as investment in clean natural gas infrastructure in China, or assistance with safe nuclear power in India (Victor 2007). Under this approach, unlike in the case of generous emissions allowances within an international permit trading regime, industrialized countries would obtain no direct return for these flows in the form of own compliance-cost reductions. Thus, it is hard to imagine there would be much support for this approach among industrialized nations.

The experience of the EU ETS, the strong U.S. preference for trading, and support voiced by some key developing countries ${ }^{37}$ represent important political arguments for this element of a future international climate policy architecture. International permit trading - not among countries, per se, but among firms within and across countries - thus remains a promising approach to achieving global greenhouse targets, despite the challenges that exist. It is probably fair to state that the more one studies international tradable permit systems to address global climate change, the more one comes to believe that this is the worst possible approach - except, of course, for all the others (bringing to mind Winston Churchill’s famous observation about democracy). ${ }^{38}$

\section{CONCLUSION}

The three-part global climate policy architecture we have proposed builds upon the U.N. Framework Convention on Climate Change and could potentially serve as a successor to the Kyoto Protocol. For such an approach to work, key nations have to be involved, including major developing countries through the use of economic trigger mechanisms such as growth targets. In addition, cost-effective time paths of targets are required: firm, but moderate in the short term, and in the long term, much more stringent and flexible. Finally, market-based policy instruments ought to be part of the package, whether emissions trading, carbon taxes, or hybrids of the two.

This overall approach can be made to be scientifically sound, economically rational, and perhaps politically pragmatic. There is no denying that the challenges facing adoption and successful implementation of this climate policy architecture are significant, but they need not be insurmountable, and they are not any greater than the challenges facing other approaches to the threat of global climate change.

\footnotetext{
${ }^{37}$ By the time of the COPs in Bonn (summer 2001) and Marrakech (fall 2001), China and the G-77 (the coalition of developing nations) had, in effect, dropped their opposition to international emissions trading.

38“"It has been said that "democracy is the worst form of government, except all those other forms that have been tried from time to time." This is the most common form of the quotation, and is reproduced from debate in the House of Commons, November 11, 1947 (James 1974).
} 


\section{REFERENCES}

Aldy, Joseph E., Scott Barrett, and Robert N. Stavins. 2003. "Thirteen Plus One: A Comparison of Global Climate Policy Architectures.” Climate Policy 3(4):373-97.

Aldy, Joseph E., R. Baron, and L. Tubiana. 2003. “Addressing Cost: The Political Economy of Climate Change.” In: Beyond Kyoto: Advancing the International Effort Against Climate Change, ed. Elliot Diringer. Arlington, Virginia: Pew Center on Global Climate Change, pp. 85-110.

Agarwala, Ramgopal. 2008. “Towards a Global Compact for Managing Climate Change.” Discussion Paper 08-22, Harvard Project on International Climate Agreements, Belfer Center for Science and International Affairs, Harvard Kennedy School, December.

Andersen, M. S. 2002. “Regulation or Coordination: European Climate Policy Between Scylla and Charybdis.” Paper presented at 10th Symposium of the Egon Sohmen Foundation, "Climate Protection and Emissions Trading U.S. and European Views,” Dresden, Germany, October 25-26.

Barrett, Scott. 2008. “A Portfolio System of Climate Treaties.” Discussion Paper 08-13, Harvard Project on International Climate Agreements, Belfer Center for Science and International Affairs, Harvard Kennedy School, October.

Barrett, Scott, and Robert N. Stavins. 2003. "Increasing Participation and Compliance in International Climate Change Agreements.” International Environmental Agreements: Politics, Law and Economics 3(4): 349-76.

Blanford, Geoffrey J., Richard G. Richels, and Thomas F. Rutherford. "Revised Emissions Growth Projections for China: Why Post-Kyoto Climate Policy Must Look East.” Discussion Paper 08-06, Cambridge, Mass.: Harvard Project on International Climate Agreements, September 2008.

Bodansky, Daniel. 2004. International Climate Efforts Beyond 2012: A Survey of Approaches. Arlington, Virginia: Pew Center on Global Climate Change, December.

Brunnermeier, Smita B., and Arik Levinson. 2004. "Examining the Evidence on Environmental Regulations and Industry Location,” Journal of Environment and Development 13(1): 6-41.

Bruvoll, A., and B. M. Larsen. 2004. “Greenhouse Gas Emissions in Norway: Do Carbon Taxes Work?” Energy Policy 32(4): 493-505.

Cao, Jing. 2008. "Reconciling Human Development and Climate Protection: Perspectives from Developing Countries on Post-2012 International Climate Change Policy.” Discussion Paper 08-25, Harvard Project on International Climate Agreements, Belfer Center for Science and International Affairs, Harvard Kennedy School, December.

Claussen, Eileen. 2003. “Forward,” In: Beyond Kyoto: Advancing the International Effort Against Climate Change, ed. Eliot Diringer. Arlington, Virginia: Pew Center on Global Climate Change, December.

Cooper, Richard. 1998. “Toward a Real Treaty on Global Warming,” Foreign Affairs 77(2): 66-79.

Cooper, Richard. 2001. “The Kyoto Protocol: A Flawed Concept.” FEEM Working Paper No. 52.2001, July.

Cooper, Richard. 2008. “The Case for Charges on Greenhouse Gas Emissions.” Discussion Paper 08-10, Harvard Project on International Climate Agreements, Belfer Center for Science and International Affairs, Harvard Kennedy School, October.

Convery, Frank J., and Luke Redmond. 2007. "Market and Price Developments in the European Union Emissions Trading Scheme,” Review of Environmental Economics and Policy 1(1): 88-111.

Den Elzen, M. G. J. 2002. “Exploring Climate Regimes for Differentiation of Future Commitments to Stabilise Greenhouse Gas Concentrations.” Integrated Assessment 3(2): 343-59. 
Ederington, Josh, Arik Levinson, and Jenny Minier. 2005. “Footloose and Pollution-Free,” Review of Economics and Statistics 87(1): 92-9.

Edmonds, J. , S. H. Kim, C. N. McCracken, R. D. Sands, and M. A. Wise. 1997. Return to 1990: The Cost of Mitigating United States Carbon Emissions in the Post-2000 Period. Washington, D.C.: Pacific Northwest National Laboratory, operated by Battelle Memorial Institute.

Ellerman, A. Denny. 2008. “The EU Emission Trading Scheme: A Prototype Global System?” Discussion Paper 200802, Cambridge, MA: Harvard Project on International Climate Agreements, August.

Ellerman, A. Denny, and Barbara K. Buchner. 2007. "The European Union Emissions Trading Scheme: Origins, Allocation, and Early Results,” Review of Environmental Economics and Policy 1(1): 66-87.

Ellerman, A. Denny, and Paul L. Joskow. 2008. The European Union's Emissions Trading System in Perspective, Pew Center on Global Climate Change, Washington, D.C.

Ellerman, A. Denny, Paul Joskow, Richard Schmalensee, Juan-Pablo Montero, and Elizabeth Bailey. 2000. Markets for Clean Air: The U.S. Acid Rain Program. New York: Cambridge University Press.

Frankel, Jeffrey. 1999. “Greenhouse Gas Emissions.” Policy Brief No. 52. Washington, D.C.: Brookings Institution.

Frankel, Jeffrey. 2005. "You're Getting Warmer: The Most Feasible Path for Addressing Global Climate Change Does Run Through Kyoto.” In: Trade and the Environment in the Perspective of the EU Enlargement, ed. M. Tamborra and J. Maxwell. Cheltenham, United Kingdom: Edward Elgar, pp. 37-58.

Frankel, Jeffrey. 2008. "An elaborated proposal for global climate policy architecture: Specific formulas and emission targets for all countries in all decades," Discussion Paper 2008-08, Cambridge, MA: Harvard Project on International Climate Agreements, October.

Garnaut, Ross, Ligang Song, Wing Thye Woo. 2009. China's New Place in a World in Crisis. Washington: Brookings Institution Press.

Goulder, Lawrence H., and Stephen H. Schneider. 1999. "Induced Technological Change and the Attractiveness of $\mathrm{CO}_{2}$ Abatement Policies.” Resource and Energy Economics 21(3-4): 211-53.

Gregg, Jay S., Robert J. Andres, and Gregg Marland. 2008. "China: Emissions pattern of the world leader in $\mathrm{CO}_{2}$ emissions from fossil fuel consumption and cement production,” Geophysical Research Letters 35, L08806, doi:10.1029/2007GL032887.

Grubb, Michael. 2003. “The Economics of the Kyoto Protocol,” World Economics 4(3): 143-89.

Guan, Dabo, Glen P. Peters, Christopher L. Weber, and Klaus Hubacek. 2009. "Journey to the world top emitter: An analysis of the driving forces of China's recent $\mathrm{CO}_{2}$ emissions surge," Geophysical Research Letters 36, L04709, doi: 10.1029/2008GL036540.

Hahn, Robert W. 1984. “Market Power and Transferable Property Rights,” Quarterly Journal of Economics 99:753765.

Hahn, Robert W., and Robert N. Stavins. 1999. What Has the Kyoto Protocol Wrought? The Real Architecture of International Tradable Permit Markets. Washington, D.C.: American Enterprise Institute Press.

Hall, Daniel S., Michael Levi, William A. Pizer, and Takahiro Ueno. 2008. "Policies for Developing Country Engagement.” Discussion Paper 08-15, Harvard Project on International Climate Agreements, Belfer Center for Science and International Affairs, Harvard Kennedy School, October. 
Hammitt, James. 1999. "Evaluating Endpoints and Climate Policy: Atmospheric Stabilization, Benefit-Cost Analysis, and Near-Term Greenhouse Gas Emissions.” Climatic Change 41(3-4):447-68.

Harstad, Bard. 2008. "How to Negotiate and Update Climate Agreements.” Discussion Paper 08-19, Harvard Project on International Climate Agreements, Belfer Center for Science and International Affairs, Harvard Kennedy School, November.

Heller, Thomas C., and P. R. Shukla. 2003. "Development and Climate: Engaging Developing Countries.” In: Beyond Kyoto: Advancing International Effort Against Climate Change, ed. Elliot Diringer. Arlington, Virginia: Pew Center on Global Climate Change, pp. 111-140.

Hockenstein, Jeremy B., Robert N. Stavins, and Bradley W. Whitehead. 1997. "Crafting the Next Generation of MarketBased Environmental Tools.” Environment, May 1997, 12-20 and 30-33.

Jacoby, Henry D. and A. Denny Ellerman. 2004. “The Safety Valve and Climate Policy.” Energy Policy 32(4): 481-91.

Jaffe, Adam B., Richard G. Newell, and Robert N. Stavins. 1999. "Energy-Efficient Technologies and Climate Change Policies: Issues and Evidence.” Climate Issue Brief No. 19. Washington, D.C.: Resources for the Future. Reprinted in Michael A. Toman, ed. 2001. Climate Change Economics and Policy. Washington, DC: Resources For the Future, pp. 171-181.

Jaffe, Adam B., Richard G. Newell, and Robert N. Stavins. 2003. “Technological Change and the Environment.” In: Handbook of Environmental Economics, Volume I, ed. Karl-Goran Mäler and Jeffrey Vincent. Amsterdam: Elsevier Science, pp. 461-516.

Jaffe, Adam B., Steven R. Peterson, Paul R. Portney, and Robert N. Stavins. 1995. "Environmental Regulation and the Competitiveness of US Manufacturing: What Does the Evidence Tell Us?” Journal of Economic Literature 33(March): 132-63.

Jaffe, Judson, and Robert N. Stavins. 2008. "Linkage of Tradable Permit Systems in International Climate Policy Architecture.” Discussion Paper 2008-07, Cambridge, MA: Harvard Project on International Climate Agreements, September.

James, R. R., ed. 1974. Winston S. Churchill: His Complete Speeches, 1897-1963, Volume 7. New York: Chelsea House.

Kagan, Robert. 2002. “Power and Weakness.” Policy Review 113: 3-28.

Keeler, Andrew G. and Alexander Thompson. 2008. "Industrialized-Country Mitigation Policy and Resource Transfers to Developing Countries: Improving and Expanding Greenhouse Gas Offsets.” Discussion Paper 08-05, Harvard Project on International Climate Agreements, Belfer Center for Science and International Affairs, Harvard Kennedy School, September.

Kopp, Raymond J., Richard D. Morgenstern, William A. Pizer, and Michael A. Toman. 2000. "A Proposal for Credible Early Action in US Climate Policy.” In: Flexible Mechanisms for Efficient Climate Policy: Cost Saving Policies and Business Opportunities, ed. K. L. Brockmann and M. Stonzik. Heidelberg, Germany: PhysicaVerlag.

Kolstad, Charles D., and Michael Toman. 2001. “The Economics of Climate Policy.” Discussion Paper 00-40REV. Washington, D.C.: Resources for the Future. Reprinted in Karl-Goran Mäler and Jeffrey Vincent, eds., Handbook of Environmental Economics, Volume II. Amsterdam: Elsevier Science.

Kruger, J. A. and W. A. Pizer. 2004. “Greenhouse Gas Trading In Europe: The New Grand Policy Experiment.” Environment, November 2004, pp. 8-23. 
Lackner, Klaus. 2005. “Carbon Management Technology.” Paper presented at “Global Warming: Looking Beyond Kyoto,” Yale University, New Haven, Connecticut, October 21-22.

Levinson, Arik. 1996. "Environmental Regulations and Industry Location: International and Domestic Evidence.” In: Fair Trade and Harmonization: Prerequisites for Free Trade? Vol. 1, ed. J. N. Bhagwati and R. E. Hudec, Cambridge, MA: MIT Press, pp. 429-57.

Lindzen, Richard. 1992. “Global Warming, The Origin and Nature of the Alleged Scientific Consensus.” Regulation 15(2).

Lindzen, Richard. 2008. “Is the Global Warming Alarm Founded on Fact?” In: Global Warming: Looking Beyond Kyoto, ed. Ernesto Zedillo. Washington, DC: Center for the Study of Globalization, Yale University and Brookings Institution Press, pp. 21-33.

Longhai, Shen. 2008. "Correct Choices for China: Energy Conservation, a Cyclic Economy, and a Conservation-Minded Society.” In: Global Warming: Looking Beyond Kyoto, ed. Ernesto Zedillo. Washington, DC: Center for the Study of Globalization, Yale University and Brookings Institution Press, pp. 215-223.

Lutter, Randall. 2000. "Developing Countries' Greenhouse Emissions: Uncertainty and Implications for Participation in the Kyoto Protocol.” The Energy Journal 21(4): 93-120.

Manne, Alan and Richard Richels. 1997. On Stabilizing $\mathrm{CO}_{2}$ Concentrations - Cost-Effective Emission Reduction Strategies. Stanford, California: Stanford University and Electric Power Research Institute, April.

Manne, Alan and Richard Richels. 2004. "U.S. Rejection of the Kyoto Protocol: The Impact on Compliance Costs and $\mathrm{CO}_{2}$ Emissions." Energy Policy 32(4): 447-54.

McKibbin, Warrick and Peter Wilcoxen. 2002 “The Role of Economics in Climate Change Policy.” Journal of Economic Perspectives 16(2):107-29.

McKibbin, Warrick and Peter Wilcoxen. 2004. "Estimates of the Costs of Kyoto: Marrakesh versus the McKibbinWilcoxen Blueprint.” Energy Policy 32(4): 467-479.

Mendelsohn, Robert. 2008. "The Policy Implications of Climate Change Impacts.” In: Global Warming: Looking Beyond Kyoto, ed. Ernesto Zedillo. Washington, DC: Center for the Study of Globalization, Yale University and Brookings Institution Press, pp. 82-88.

Metcalf, Gilbert. 2007. A Proposal for a U.S. Carbon Tax Swap: An Equitable Tax Reform to Address Global Climate Change. Discussion Paper 2007-12, Hamilton Project, Brookings Institute.

Metcalf, Gilbert. 2009. “Market-based Policy Options to Control U.S. Greenhouse Gas Emissions.” Journal of Economic Perspectives 23.2 (2009): 5-27.

Metcalf, Gilbert and David Weisbach. 2009. “The Design of a Carbon Tax.” Harvard Environmental Law Review 33.2 (2009): 499-506.

Michaelowa, Axel. 2003. “Global Warming Policy.” Journal of Economic Perspectives 17(3): 204-05.

Michaelowa, A., M. Stronzik, F. Eckermann, and A. Hunt. 2003. “Transaction Costs of the Kyoto Mechanisms.” Climate Policy 3(3): 261-78.

Murray, Brian, Richard Newell, and William Pizer. 2009. "Balancing cost and emissions certainty: An allowance reserve for cap-and-trade.” Review of Environmental Economics and Policy, vol. 3 no. 1 (Winter, 2009), pp. 84-103. 
Nakicenovic, N. and R. Swart, eds. 2000. Intergovernmental Panel on Climate Change Special Report on Emissions Scenarios. Cambridge, United Kingdom: Cambridge University Press.

National Commission on Energy Policy. 2004. Ending the Energy Stalemate: A Bipartisan Strategy to Meet America's Energy Challenges.” Washington, DC: National Commission on Energy Policy, December.

Newell, Richard G. 2008. “International Climate Technology Strategies.” Discussion Paper 08-12, Harvard Project on International Climate Agreements, Belfer Center for Science and International Affairs, Harvard Kennedy School, October.

Newell, Richard G., and William A. Pizer. 2003. "Regulating Stock Externalities Under Uncertainty.” Journal of Environmental Economics and Management 45(2, suppl. 1): 416-32.

Nordhaus, William D., and Joseph Boyer. 2000. Warming the World: Economic Models of Global Warming. Cambridge: MIT Press.

Nordhaus, William D. 2008a. “Economic Analyses of Kyoto Protocol: Is There Life After Kyoto?” In: Global Warming: Looking Beyond Kyoto, ed. Ernesto Zedillo. Washington, DC: Center for the Study of Globalization, Yale University and Brookings Institution Press, pp. 91-100.

Nordhaus, William D. 2008b. A Question of Balance: Weighing the Options on Global Warming Policies. New Haven: Yale University Press.

Pachauri, Rajendra K. 2008. “The IPCC: Establishing the Evidence.” In: Global Warming: Looking Beyond Kyoto, ed. Ernesto Zedillo. Washington, DC: Center for the Study of Globalization, Yale University and Brookings Institution Press, pp. 13-20.

Paltsev, S. V. 2001. “The Kyoto Protocol: Regional and Sectoral Contributions to the Carbon Leakage.” The Energy Journal 22(4): 53-79.

Parikh, Jyoti K. 2008. “India and Climate Change: Mitigation, Adaptation, and a Way Forward.” In: Global Warming: Looking Beyond Kyoto, ed. Ernesto Zedillo. Washington, DC: Center for the Study of Globalization, Yale University and Brookings Institution Press, pp. 205-214.

Pershing, J., and F. Tudela. 2003. “A Long-Term Target: Framing the Climate Effort.” In: Beyond Kyoto: Advancing the International Effort Against Climate Change, ed. Eliot Diringer. Arlington, Virginia: Pew Center on Global Climate Change, pp. 11-36.

Pies, I., and G. Schröder. 2002. Causes and Consequences of Global Warming: How Rational is Our Policy on Climate Change? Munich: Policy Consult.

Pizer, William A. 2002. “Combining Price and Quantity Controls to Mitigate Global Climate Change.” Journal of Public Economics 85(3): 409-34.

Potomac Economics. 2009. Report on the Secondary Market for RGGI $\mathrm{CO}_{2}$ Allowances. Washington, DC: Potomac Economics, May.

Reis, Eustáquio. 2005. “Linking Climate Change Control and Development Policies: The Brazilian Case.” Paper presented at "Global Warming: Looking Beyond Kyoto,” Yale University, New Haven, Connecticut, October 21-22.

Richels, Richard G., Alan S. Manne, and Thomas M. L. Wigley. 2004. "Moving Beyond Concentrations — The Challenge of Limiting Temperature Change." AEI-Brookings Joint Center working paper no. 04-11 Washington, D.C.: AEI-Brookings Joint Center. 
Roberts, Mark, and Michael Spence. 1976. “Effluent Charges and Licenses under Uncertainty.” Journal of Public Economics 5(3-4): 193-208.

Schmalensee, Richard. 1998. “Greenhouse Policy Architecture and Institutions,” In: Economics and Policy Issues in Climate Change, ed. William D. Nordhaus.. Washington, D.C.: Resources for the Future.

Schmalensee, Richard, Paul Joskow, Denny Ellerman, Juan-Pablo Montero, and Elizabeth Bailey. 1998. "An Interim Evaluation of Sulfur Dioxide Emissions Trading.” Journal of Economic Perspectives 12(3): 53-68.

Shogren, Jay F., and Michael A. Toman. 2000. "Climate Change Policy.” In: Public Policies for Environmental Protection, Second Edition, ed. Paul R. Portney and Robert N. Stavins. Washington, DC: Resources for the Future, pp. 125-168.

Somanathan, E. 2008. "What Do We Expect from an International Climate Agreement? A Perspective from a Low-income Country.” Discussion Paper 08-27, Harvard Project on International Climate Agreements, Belfer Center for Science and International Affairs, Harvard Kennedy School, December.

Springer, U., and M. Varilek.. 2004. "Estimating the Price of Tradable Permits for Greenhouse Gas Emissions in 2008-12.” Energy Policy 32(5): 611-21.

Stavins, Robert N. 1995. "Transaction Costs and Tradeable Permits." Journal of Environmental Economics and Management 29(2): 133-48.

Stavins, Robert N. 1997. "Policy Instruments for Climate Change: How Can National Governments Address a Global Problem?” The University of Chicago Legal Forum, 1997, pp. 293-329.

Stavins, Robert N. 1998. "What Can We Learn from the Grand Policy Experiment? Lessons from $\mathrm{SO}_{2}$ Allowance Trading.” Journal of Economic Perspectives, 12(3): 69-88.

Stavins, Robert N. 2003. “Experience with Market-Based Environmental Policy Instruments.” In: Handbook of Environmental Economics, Volume I, ed. Karl-Goran Mäler and Jeffrey Vincent. Amsterdam: Elsevier Science, pp. 355-435.

Sugiyama, T., and L. Deshun. 2004. "Must Developing Countries Commit [to] Quantified Targets? Time Flexibility and Equity in Climate Change Mitigation.” Energy Policy 32(5): 697-704.

Teng, Fei, Wenying Chen, and Jiankun He. 2008. "Possible Development of a Technology Clean Development Mechanism in a Post-2012 Regime.” Discussion Paper 08-24, Harvard Project on International Climate Agreements, Belfer Center for Science and International Affairs, Harvard Kennedy School, December.

Toman, Michael A., Ujjayant Chakravorty, and Shreekant Gupta. 2003. India and Global Climate Change: Perspectives on Economics and Policy from a Developing Country. Washington, D.C.: Resources for the Future Press.

United Nations. 1992. "United Nations Framework Convention on Climate Change.”

United Nations. 1997. "Kyoto Protocol to the Convention on Climate Change.”

U.S. Energy Information Administration. 2009. International Energy Outlook 2009. Report No. DOE/EIA-0484(2009). Washington, DC: Energy Information Administration, May.

Victor, David G. 2001. The Collapse of the Kyoto Protocol and the Struggle to Slow Global Warming. Princeton, New Jersey: Princeton University Press. 
Victor, David G. 2007. "Fragmented carbon markets and reluctant nations: Implications for the design of effective architectures,” In: Architectures for Agreement: Addressing Global Climate Change in the Post-Kyoto World, ed. Joseph E. Aldy and Robert N. Stavins. New York: Cambridge University Press, pp. 133-172.

Victor, David G. 2008. Climate Accession Deals: New Strategies for Taming Growth of Greenhouse Gases in Developing Countries. Discussion Paper 08-18, Harvard Project on International Climate Agreements, Belfer Center for Science and International Affairs, Harvard Kennedy School, December.

Watson, Robert T., ed. 2001. Climate Change 2001: Synthesis Report. Contributions of Working Group I, II, and III to the Third Assessment Report of the Intergovernmental Panel on Climate Change. Cambridge, UK: Cambridge University Press.

Wigley, Thomas, Richard Richels, and Jae Edmonds. 1996. "Economic and Environmental Choices in the Stabilization of Atmospheric $\mathrm{CO}_{2}$ Concentrations." Nature 18: 240-43. 